\title{
A study of Diagnosis and surgical management of pancreatic insulinoma
}

\author{
Chinthakindi M. ${ }^{1}$, Prashanth K. ${ }^{2}$, Thogari R. ${ }^{3}$, Reddy R.P. ${ }^{4}$ \\ ${ }^{1}$ Dr. Madhusudhan Chinthakindi, Associate Professor, ${ }^{2}$ Dr. Kyyoda Prashanth, Registrar, ${ }^{3}$ Dr. Ravimohan Thogari, \\ Associate Professor, ${ }^{4}$ Dr. Ramalingam Pratap Reddy, Professor; all authors are attached with Department of Surgical \\ Gastroenterology, Osmania Medical College / Hospital, Hyderabad, Telangana, India.
}

Corresponding Author: Dr.Madhusudhan Chinthakindi, Associate Professor, Department of Surgical Gastroenterology, Osmania Medical College/Hospital, Hyderabad. Email: madhuchinthakindhi@rediffmail.com

\begin{abstract}
Introduction: Insulinomas are the most common functioning neuroendocrine tumors of the pancreas, occurring in almost 1-4 per 1 million persons each year. They pose a challenge for pre-operative localization. Many invasive and noninvasive methods exist for localization of an insulinoma. Intra-operative ultrasonography (IOUS) with palpation can be done for tumors not localized by conventional imaging modalities. Pancreas Preserving surgery is the treatment of choice. This article gives an overview on localization and surgical strategies for treatment of insulinoma. Materials and Methods: This is a retrospective data of the patients undergoing surgical treatment of insulinoma in the Osmania General Hospital, Hyderabad between 2007 to 2017. Demographic data, symptoms and diagnostic tests and type of resections were analyzed from medical records. All patients had a completeintraoperative exploration of the pancreas done by digital palpation and intra operative ultrasonography. Results: 10cases (6 males and 4 females) of insulinoma aged between 22 and 55 years, with a median age of 30 years were included in the analysis. The size of the insulinoma ranged between 1.2 to $3 \mathrm{~cm}$ with average size of $2.14 \mathrm{~cm}$. 8 patients presented with Neuro glycopenicsymptoms howeversympatho adrenergic symptoms were present in all cases. Different modalities were employed for pre-operative localization of these patients out of which 5 cases were localized with CT, 2 cases with MRI, 1 case with EUS, 2 of them could not be localized preoperatively were localized by IOUS. Tumor was in Head 2 cases, in the neck1 case and in the body/ Tail in 7 cases. 2 patients underwent Enucleation, 5 underwent distal pancreatectomy and splenectomy, 2 underwent distal pancreatectomy and 1 underwent central pancreatectomy. 4 had pancreatic leak. All are symptom free and no episode of hypoglycemia at the time of discharge. Conclusion: Insulinomas are the most common neuroendocrine tumors of the pancreas. Surgical resection is the treatment of choice for insulinomas. From a surgical standpoint, localization of the tumor is of critical importance. Intraoperative Ultrasonography with palpation gives good help in localizing the lesion.
\end{abstract}

Keywords: Hypoglycemia, Insulinoma, Intraoperative Ultrasonography, Pancreatic tumor, Pancreatectomy.

\section{Introduction}

Insulinomas are the most common functioning neuroendocrine tumors of the pancreas, occurring in almost 1-4 per 1 million persons each year [1-3]. Insulinomas are insulin-secreting neoplasms that arise from pancreatic beta cells. Sporadic insulinomas are usually solitary, benign and encapsulated small lesions. Ninety percent of them measure $<2 \mathrm{~cm}$ and with $30 \%$ being $<1 \mathrm{~cm}$ in diameter. Ten percent are multiple, $10 \%$ are malignant and $10 \%$ are associated with multiple endocrine neoplasia type 1 (MEN-1) [2-4]. Insulinomas

\footnotetext{
Manuscript Received: $27^{\text {th }}$ January 2018

Reviewed: $4^{\text {th }}$ February 2018

Author Corrected: $10^{\text {th }}$ February 2018

Accepted for Publication: $15^{\text {th }}$ Februry 2018
}

present with repeated episodes of hypoglycemia due to endogenous hyperinsulinemia, which occurs mostly in the fasting state but may sometimes occur in the postprandial period. Symptoms are categorized into the neuroglycopenic type, which result from dysfunction of the central nervous system due to a lack of glucose, its primary energy substrate, and the sympatho adrenal type which occur as part of the stress response and the subsequent release of catecholamines. Neuroglycopenic symptoms include diplopia, behavioral changes, confusion, fatigue, amnesia, seizures and even death if hypoglycemia persists for a long time. Due to stimulation of the autonomic nervous system, results in 


\section{Original Research Article}

hunger, sweating, anxiety, paresthesia's, palpitations and other adrenergic symptoms [2,4]. Historically, Whipple's triad has summarized the clinical picture and diagnosis of insulinoma (induction of the symptoms after fasting or exercise, a plasma glucose $<50 \mathrm{mg} / \mathrm{dl}$ when symptomatic, relief of symptoms after administration of oral or intravenous glucose) and is still employed today to diagnose hypoglycemic disorders in non-diabetic patients [5]. Diagnosis of an insulinoma is dependent on documenting inappropriately elevated levels of insulin in the setting of low circulating levels of glucose [4]. Once a state of incongruent hyperinsulinemia has been diagnosed, localization studies are necessary to visualize the tumor.

Surgical resection (conventional or laparoscopic) is the primary treatment modality for insulinomas, and so accurate localization of the tumor before or during surgery is important. Multiple studies have been performed in evaluating the sensitivity of both invasive and noninvasive preoperative localization techniques [4,6-10]. Additional studies have assessed the role of intraoperative ultrasound and palpation in tumor localization [4-6].Following biological and biochemical confirmation of an insulinoma, preoperative localization is sought using computed tomography (CT) [11-13], magnetic resonance imaging (MRI) [13-16], endoscopic ultrasonography (EUS) [17-19], intra-arterial calcium stimulation test with hepatic venous sampling [20], and/or angiography and arterial stimulation venous sampling (ASVS)[21-25].

The present study aims to analyze the clinical, epidemiological, Radiological findings and surgical out comes of Insulinoma treated in our institute.

\section{Materials and Methods}

Place of study and type of study: This is a retrospective data of the medical records of patients undergoing surgical treatment of insulinoma in the Osmania General Hospital, Hyderabad between 2007 to 2017.

Demographic data, type and duration of symptoms, association or not with endocrine syndrome and diagnostic tests were obtained from registries of medical records. It was also analyzed, the surgical approach, intraoperative findings and complications.

The preoperative evaluation done with USG Abdomen, Contrast enhanced CT,Abdominal MRI and Endoscopic U/S (EUS). All patients had a complete intraoperative exploration of the pancreas done by digital palpation and intra operative ultrasonography.

Cure following surgical resection was defined as normal glucose levels in the setting of fasting without either pharmacologic assistance or the need for supplemental glucose at the time of discharge from the hospital.

Inclusion criteria: Biochemically detected, surgically resected and histopathological confirmed cases of Insulinoma of pancreas were included in this study.

Exclusion criteria: if Histopathology report doesn't show Insulinoma were excluded from the study.

Statistical methods: Continuous data were expressed as median/ range and analyzed by Kruskal-Wallis test, and categorical variables were expressed as number/ percentage and analyzed by chi-square test.

\section{Results}

Ten cases of insulinoma aged between 22 and 55 years, with a median age of 30 years were included in the analysis. There were 6 males and 4 females. Nine patients presented with pre-prandial hypoglycemia. One patient had hypoglycemia during the episode of seizure. Neuro glycopenic symptoms were present in 8 patients and sympatho adrenergic symptoms were present in allcases. Six cases were Obese. 3 patients were referred from psychiatry department due neuroglycopenic symptoms caused by Hypoglycemia. Different modalities were employed for pre-operative localization of these patients out of which 5 cases were localized with CT, 2 cases with MRI, 1 case with EUS, 2 of them could not be localized preoperatively were localized by IOUS. Tumor was in Head in 2 cases, in the neck 1 case and in the body/ Tail in 7 cases [Table 1].

All underwent surgery out of which 2 patients underwent Enucleation, 5 underwent distal pancreatectomy and splenectomy, 2 underwent distal pancreatectomy and 1 underwent central pancreatectomy. The size of the insulinoma ranged between 1.2 to $3 \mathrm{~cm}$ with average size of $2.14 \mathrm{~cm}$.

Three had grade A pancreatic leak and 1 had grade B pancreatic leak (following enucleation of the head lesion). All are symptom free and no episode of hypoglycemia at the time of discharge. During follow up 1 patient developed diabetes managed with oral hypoglycemic agents. 


\section{Original Research Article}

Table-1: Showing Insulinoma patients Demographic, site, size, localizing images, type of surgery and complications.

\begin{tabular}{|c|c|c|c|c|c|c|c|}
\hline $\begin{array}{l}\text { S. } \\
\text { No }\end{array}$ & Sex/age & $\begin{array}{c}\text { Site } \\
\text { / size }\end{array}$ & $\begin{array}{c}\text { CECT } \\
\text { Abdomen }\end{array}$ & MRI & EUS & Surgery & Complication \\
\hline 1 & Female/25 & $\begin{array}{c}\text { Tail } \\
/ 2.2 \mathrm{~cm}\end{array}$ & Localized & & & $\begin{array}{l}\text { Distal pancreatectomy+ } \\
\text { splencetomy }\end{array}$ & \\
\hline 2 & Male/55 & $\begin{array}{l}\text { Body } \\
/ 1,2 \mathrm{~cm}\end{array}$ & Localized & & & $\begin{array}{c}\text { Distal pancreatectomy+ } \\
\text { splenectomy }\end{array}$ & $\begin{array}{c}\text { Grade A } \\
\text { pancreatic Leak }\end{array}$ \\
\hline 3 & Male/36 & $\begin{array}{l}\text { Body } \\
/ 2.2 \mathrm{~cm}\end{array}$ & - & - & - & $\begin{array}{l}\text { Distal pancreatectomy+ } \\
\text { splenectomy }\end{array}$ & \\
\hline 4 & Male/22 & $\begin{array}{l}\text { Body } \\
/ 2.7 \mathrm{~cm}\end{array}$ & Localized & & & $\begin{array}{c}\text { Distal pancreatectomy+ } \\
\text { splenectomy }\end{array}$ & $\begin{array}{c}\text { Grade A } \\
\text { pancreatic Leak }\end{array}$ \\
\hline 5 & Female $/ 50$ & $\begin{array}{l}\text { Tail } \\
/ 3 \mathrm{~cm}\end{array}$ & & Localized & & Distal pancreatectomy & \\
\hline 6 & Male/32 & $\begin{array}{l}\text { Head } \\
/ 2 \mathrm{~cm}\end{array}$ & Localized & & & Enucleation & $\begin{array}{c}\text { Grade B } \\
\text { pancreatic Leak }\end{array}$ \\
\hline 7 & Female/24 & $\begin{array}{l}\text { Neck } \\
/ 1.8 \mathrm{~cm}\end{array}$ & & & Localized & $\begin{array}{c}\text { Central } \\
\text { pancreatectomy }\end{array}$ & \\
\hline 8 & Female/28 & $\begin{array}{l}\text { Body } \\
/ 2.3 \mathrm{~cm}\end{array}$ & - & - & - & $\begin{array}{l}\text { Distal pancreatectomy+ } \\
\text { splenectomy }\end{array}$ & \\
\hline 9 & Male/32 & $\begin{array}{l}\text { Body } \\
/ 1.9 \mathrm{~cm}\end{array}$ & & Localized & & Distal pancreatectomy & \\
\hline 10 & Male/26 & $\begin{array}{l}\text { Head } \\
/ 2.3 \mathrm{~cm}\end{array}$ & Localized & & & Enucleation & $\begin{array}{c}\text { Grade A } \\
\text { Pancreatic Leak }\end{array}$ \\
\hline
\end{tabular}
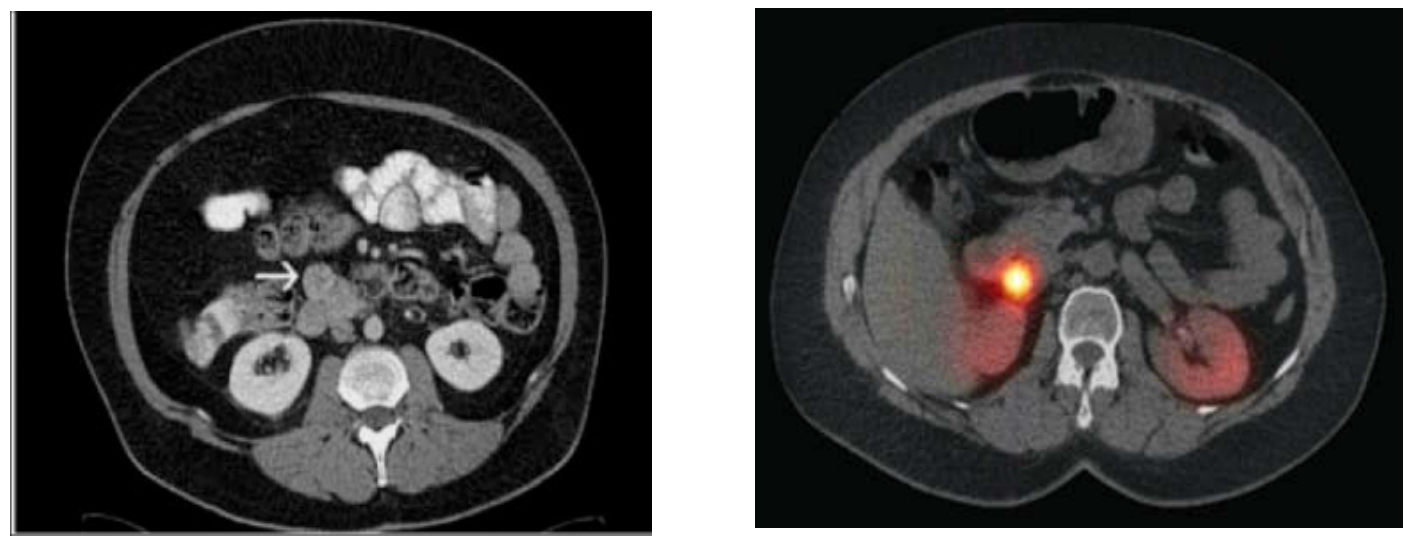

Fig-1(A):CECT Abdomen showing mass at Head of pancreas, Fig-1(B):PET CT hyper active lesion at Head of pancreas
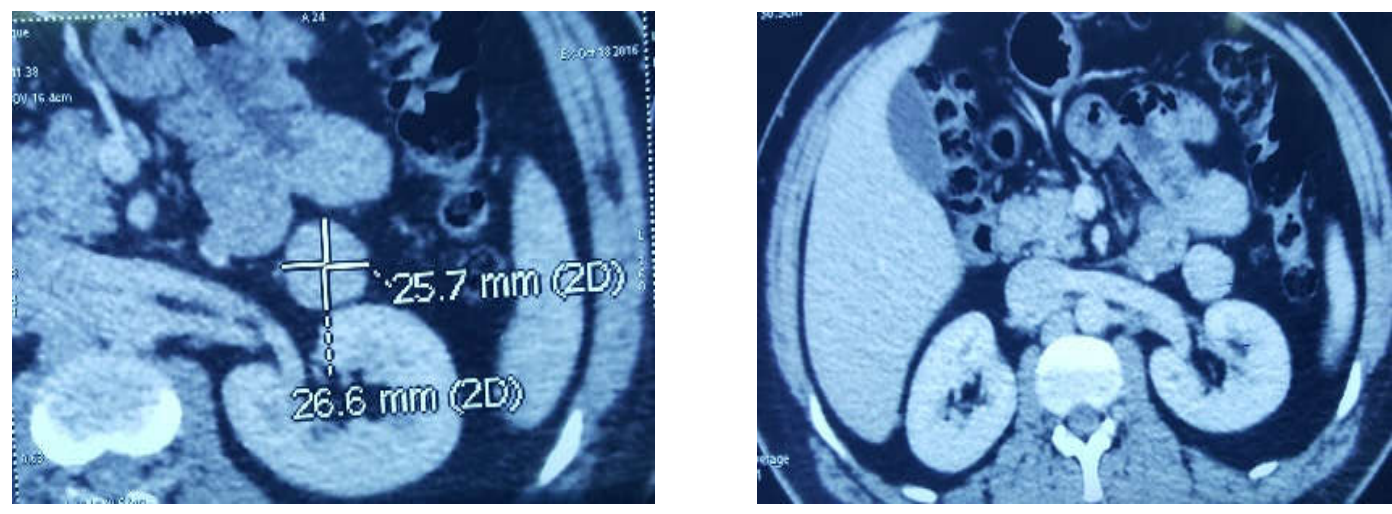

Fig 2(A):CECT Abdomen showing lesion at Tail of pancreas Fig2(B):CECT Abdomen showing 2.67x2.66 cm insulinoma 


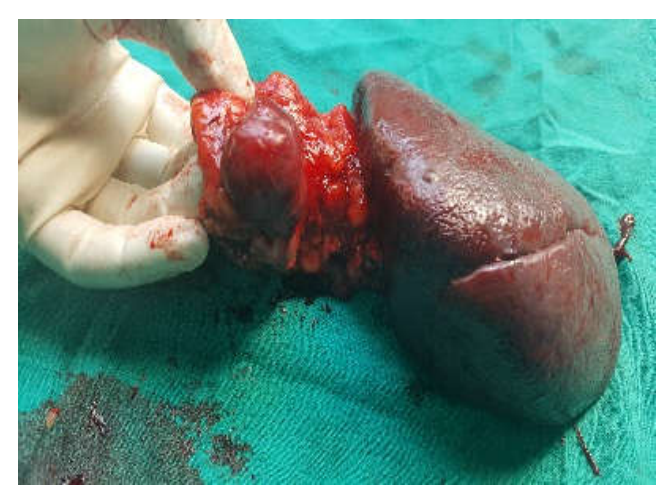

Fig 2(C): Distal pancreatectomy with insulinoma +splenectomy.

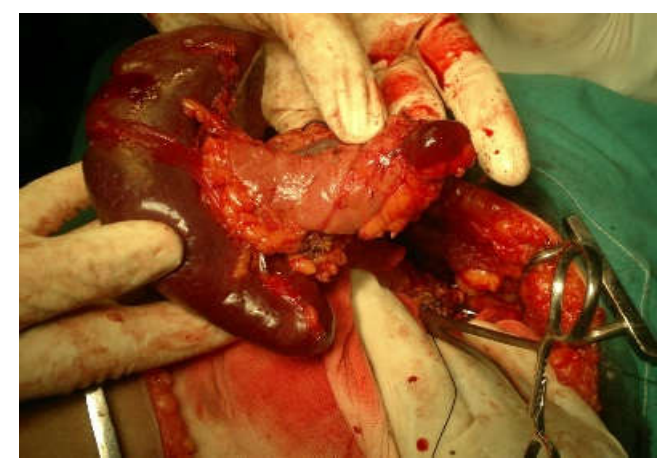

Fig 3 (A) Distal pancreatectomy with splenectomy for insulinoma.

\section{Discussion}

Insulinomas are the most common functioning neuroendocrine tumors of the pancreas, occurring in almost 1-4 per 1 million persons each year [1-3]. Insulinomas are insulin-secreting neoplasms that arise from pancreatic beta cells. Sporadic insulinomas are usually solitary, benign and encapsulated small lesions. Ninety percent of them measure $<2 \mathrm{~cm}$ and with $30 \%$ being $<1 \mathrm{~cm}$ in diameter. Ten percent are multiple, $10 \%$ are malignant and $10 \%$ are associated with multiple endocrine neoplasia type 1 (MEN-1) [2-3]. In a non-diabetic individual with fasting hypoglycemia, insulinoma should be considered in the differential diagnosis. Clinical presentation can vary, they may present with adrenergic symptoms like palpitations, tremor, anxiety, warmth and dry mouth, cholinergic symptoms comprising of hunger, sweating and paresthesia's [3-4].

Neuroglycopenic symptoms start as a blood glucose falls to approximately $50-55 \mathrm{mg} / \mathrm{dL}(2.8-3.1 \mathrm{mmol} / \mathrm{L})$, which include slurred speech, blurred vision, confusion, drowsiness and difficulty in concentrating [2-4]. A strong clinical suspicion to diagnose an insulinoma with varied clinical presentation is needed. These patients tend to eat more to avoid symptoms of hypoglycemia

\section{Original Research Article}

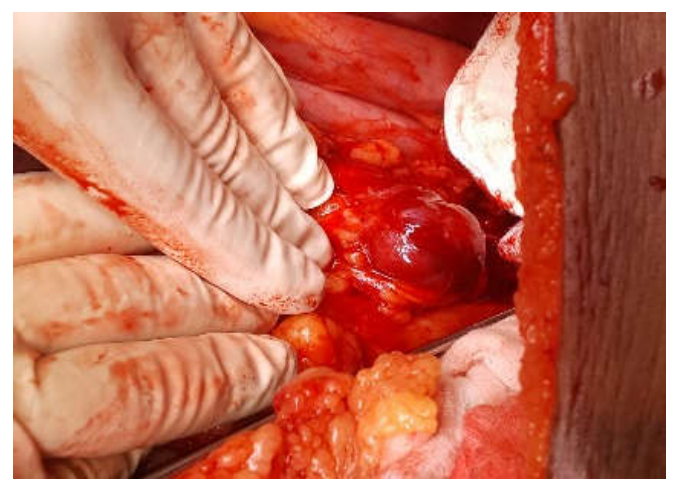

Fig 2 (D): Intra operative picture of Insulinoma at tail of pancreas

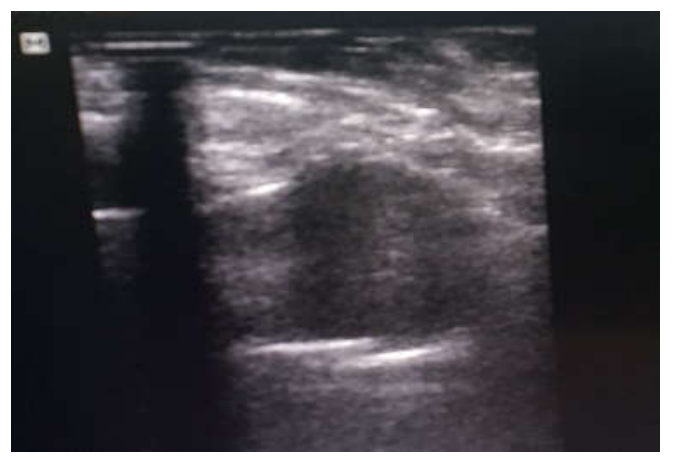

Fig 3 (B) Intraoperative Ultrasonography showing Insulinoma on posterior aspect of body of pancreas

and thus they become overweight and obese. Historically, Whipple's triad has summarized the clinical picture and diagnosis of insulinoma (induction of the symptoms after fasting or exercise, a plasma glucose $<50 \mathrm{mg} / \mathrm{dl}$ when symptomatic, relief of symptoms after administration of oral or intravenous glucose) and is still employed today to diagnose hypoglycemic disorders in non-diabetic patients [5].

Diagnosis of an insulinoma is dependent on documenting inappropriately elevated levels of insulin in the setting of low circulating levels of glucose. The measurement of serum insulin has proven useful for the diagnosis, and it is important the demonstration of elevated insulin ( $>5$ microU $/ \mathrm{mL}$ ) during an episode of symptomatic hypoglycemia. The relationship between insulin (microU / $\mathrm{ml}$ ) and glucose $(\mathrm{mg} / \mathrm{dL})>0.4$ is highly suggestive, as well as increased levels of Cpeptide ( $>2 \mathrm{nmol} / \mathrm{L}$ )[3,8]. Increased levels of Cpeptide are also valuable diagnostic, excluding the possibility of fictional disease [26].

Once a state of incongruent hyper insulinemia has been diagnosed, localization studies are necessary to visualize the tumor. Our experience in localizing 


\section{Original Research Article}

insulinomas with different imaging modalities is similar to other series [27, 32]. Preoperative localization in the present series was successful in $80 \%$ of cases, different modalities were employed for preoperative localization [Table 1]; 5 (50\%) cases were localized with CT, 2 cases (20\%) with MRI, 1 (10\%) with endosonographic (EUS), $2(20 \%)$ cases could not be localized preoperatively. These $2(20 \%)$ cases were localized by intra-operative palpation and ultrasonography.

Thus, more percentage of cases were localized preoperatively in our series as compared to the data by Jyotsna et al., where preoperative localization of insulinoma was successful in $71 \%$ with various imaging modalities, with CT angiography, 83\%, intraarterial digital subtraction angiography, 65\%, dual-phase CT, $57 \%$, and conventional MRI in $31 \%$ and intraoperative palpation and ultrasonography localized $76 \%$ and $92 \%$, respectively [33]. In Kaczirek et al. series, insulinoma was localized by conventional CT in 33\%, single-slice helical CT in 58\%, multi-detector CT in $100 \%$, MRI in $85 \%$ and invasive angiography in $65 \%$ and with a combination of different modalities, the sensitivity rate was up to $88 \%$ [34].

When conventional imaging modalities cannot localize, intra operative ultrasonography with bimanual palpation willhelp.

Surgical excision of insulinoma remains the treatment of choice [35,36]. Traditional resections and parenchyma-sparing resections or a combination of both can be employed depending on indications. Factors that dictate the choice of procedure and should be addressed preoperatively are a diagnosis or not of MEN1, the number of insulinomas, the tumor's size, location in the pancreas and anatomical proximity to the major pancreatic duct and major blood vessels, and the likelihood of malignancy. As previously stated, the majority of insulinomas are sporadic and in turn most sporadic insulinomas are solitary and benign.

Therefore, parenchyma-sparing procedures such as enucleation and central pancreatectomy are frequently performed in the management of sporadic insulinoma.In this study, the tumor was slightly more prevalent in the body and tail $(70 \%)$, and the literature shows equal distribution in the pancreatic parenchyma $[2,3]$.

Although no patients required a pancreatic coduodenectomy in our series, it has been required in $5.5 \%$ to $16 \%$ of cases involving pancreatic head tumors in which main pancreatic duct injury is a concern [1,37].
Enucleation is safe if the lesion is located 2-3mm away from the main pancreatic duct. All pancreatic head lesions $(\mathrm{N}=2)$ in our study were removed via enucleation. Following enucleation inspection of the resection site under $3.5 \times$ loupe magnification for evidence of a pancreatic duct leak was performed. An alternative technique to pancreatic coduodenectomy or pancreatic head resection with Roux-en-Y pancreatojejunostomy to spare the duodenum and the normal pancreatic body and tail [38].

In this study, 5 patients underwent distal pancreatectomy and splenectomy due to tumor was proximity to splenic vessels and larger size. 2 patients underwent spleen preserving distal pancreatectomy and 1 underwent central pancreatectomy. The spleen can be preserved in patients undergoing a distal pancreatectomy as advised by reports suggesting patients undergoing spleen-preserving procedures have less postoperative complications including infection [4,39].

All procedures in the current study were performed via a laparotomy. Advances in laparoscopic techniques have resulted in recent studies proposing the use of laparoscopic enucleation or pancreatectomy with or without intraoperative ultrasound for the management of insulinomas in adults [40-43]. Although these studies are encouraging, we prefer laparotomy for the management of insulinomas mainly due to the critical role of intraoperative palpation and intraoperative ultrasound in identifying the lesions. We believe it is important to explore and palpate the entire pancreas and use intraoperative ultrasound to avoid missing lesions.

Recently, successful EUS-guided alcohol ablation and CT-guided RFA of pancreatic insulinomas have been reported in humans with poor general condition and were experiencing recurrent symptomatic episodes of hypoglycemia $[44,45]$. Both patients were discharged without any complications and reported no further hypoglycemic episodes.

Embolization of an insulinoma of the pancreas is another non-surgical alternative [46,47]. Medical treatment to normalize blood glucose is useful during the preoperative period, as well as for patients who cannot be cured by surgery, such as those with diffuse $\beta$-cell disease, multiple insulinomas, unresectable malignant insulinoma, those in whom surgery is contraindicated, or patients who refuse surgery [48]. Octreotide is a somatostatin analog that inhibits insulin secretion and the peripheral action of many gastrointestinal hormones, primarily via activation of 


\section{Original Research Article}

somatostatin sst 2 receptors. Octreotide has been used for the treatment of insulinoma, with successful control of blood glucose levels [49,50].

There were no deaths. The post- operative morbidity was $40 \%$, being the main cause pancreatic fistula. Of these, however, there was spontaneous resolution in all cases, except in one was managed with percutaneous drainage and pancreatic stent placement with the longest hospital stay of 32 days.

This is consistent with bonito et al where he noted $43.7 \%$ of pancreatic leak and all are resolved conservatively [51]. Almost all patients had immediate solving of their symptoms, presenting hyperglycemia within the first days post-operatively. In one case developed diabetes during follow up.

\section{Conclusion}

Insulinomas are the most common neuroendocrine tumors of the pancreas and cause hypoglycemia related to endogenous hyperinsulinism. More than $90 \%$ of insulinomas are benign and usually small, wellencapsulated, solitary tumors. Surgical resection is the treatment of choice for insulinomas and offers the only chance for cure. From a surgical standpoint, localization of the tumor is of critical importance. Successful identification eliminates the need for blind resections of pancreatic tissue. However, no consensus has been attained for the preoperative localization of these tumors.

Local availability and skill in specific invasive and noninvasive tests seem to determine the preoperative algorithm. Intraoperative Ultrasonography with palpation gives good help in localizing the lesion.

Advances in minimally invasive surgical techniques have for the last two decades permitted the introduction of laparoscopic surgery in the treatment of this condition. Results have been encouraging and comparable to those of open surgical techniques. However, there is an absence of randomized control studies that would conclusively verify the conclusions of these studies.

Message of this study: From a surgical standpoint, localization of the tumor is of critical importance. Successful identification eliminates the need for blind resections of pancreatic tissue.

Intraoperative Ultrasonography with bimanual palpation gives good help in localizing the lesion.

\section{Authors Contribution}

Author 1. Prepared the manuscript and performed all surgeries.

Author 2. Helped in data collection and involved in patient care.

Author 3. Helped in data analysis and statistical analysis. Assisted majority of surgeries.

Author 4. Supervised the paper and involved in patient care of these patients.

Conflict of interest: None declared.

Funding: Nil, Permission from IRB: Yes

\section{References}

1. Nikfarjam M, Warshaw AL, Axelrod L, Deshpande V, Thayer SP, Ferrone CR, Fernández-del Castillo C. Improved contemporary surgical management of insulinomas: a 25-year experience at the Massachusetts General Hospital. Ann Surg. 2008 Jan; 247 (1): 165-72.

2. Grant CS. Insulinoma Best Pract Res Clin Gastroenterol. 2005 Oct;19(5):783-98.

3. Service FJ, McMahon MM, O'Brien PC, Ballard DJ. Functioninginsulinoma--incidence, recurrence, and long - term survival of patients: a 60-year study. Mayo Clin Proc. 1991 Jul;66(7):711-9.

4. Tucker ON, Crotty PL, Conlon KC. The management of insulinoma.Br J Surg. 2006 Mar;93(3):264-75.

5. Mathur A, Gorden P, Libutti SK. Insulinoma. Surg Clin North Am. 2009 Oct; 89(5): 1105-21. doi: 10. 1016/ j.suc.2009.06.009.

6. Ravi K,Britton BJ. Surgical approach to insulinomas: are pre-operative localisation tests necessary? Ann R Coll Surg Engl.2007 Apr;89(3):212-7.

7. Vinik AI, Delbridge L, Moattari R, Cho K, Thompson N. Transhepatic portal vein catheterization for localization of insulinomas: a ten-year experience. Surgery.1991 Jan; 109(1):1-11; discussion 111.

8. Wiesli P, Brändle M, Schmid C, Krähenbühl L, Furrer J, Keller U, Spinas GA, Pfammatter T. Selective arterial calcium stimulation and hepatic venous sampling in the evaluation of hyper insulinemichypoglycemia: potential and limitations.J Vasc Interv Radiol. 2004 Nov;15(11):1251-6. 


\section{Original Research Article}

9. Anderson MA, Carpenter S, Thompson NW, Nostrant TT, Elta GH, Scheiman JM. Endoscopic ultrasound is highly accurate and directs management in patients with neuroendocrine tumors of the pancreas. Am J Gastroenterol. 2000 Sep;95(9):2271-7.

10. Chung JC, Choi SH, Jo SH, Heo JS, Choi DW, Kim YI. Localization and surgical treatment of the pancreatic insulinomas.ANZ J Surg. 2006 Dec;76(12):1051-5.

11. Chatziioannou A, Kehagias D, Mourikis D, Antoniou A, Limouris G, Kaponis A, Kavatzas N, Tseleni S, Vlachos L. Imaging and localization of pancreatic insulinomas.Clin Imaging. 2001 Jul-Aug; 25 (4): 275-83.

12. Sheth S, Hruban RK, Fishman EK. Helical CT of islet cell tumors of the pancreas: typical and atypical manifestations.AJR Am J Roentgenol. 2002 Sep;179 (3): 725-30.

13. Noone TC, Hosey J, Firat Z, Semelka RC. Imaging and localization of islet-cell tumours of the pancreas on CT and MRI.Best Pract Res Clin Endocrinol Metab. 2005 Jun;19(2):195-211.

14. Owen NJ,Sohaib SA, Peppercorn PD, Monson JP, Grossman AB, Besser GM, Reznek RH. MRI of pancreatic neuroendocrine tumours.Br J Radiol. 2001 Oct; 74 (886):968-73.

15. Thoeni RF, Mueller-Lisse UG, Chan R, Do NK, Shyn PB. Detection of small, functional islet cell tumors in the pancreas: selection of MR imaging sequences for optimal sensitivity. Radiology. 2000 Feb; 214 (2): 483-90.

16. Anaye A, Mathieu A, Closset J, Bali MA, Metens T, Matos C. Successful preoperative localization of a small pancreatic insulinoma by diffusion-weighted MRI.JOP. 2009 Sep 4;10(5):528-31.

17. Kann PH, Ivan D, Pfützner A, Forst T, Langer P, Schaefer S. Preoperative diagnosis of insulinoma: low body mass index, young age, and female gender areassociated with negative imaging by endoscopic ultrasound. Eur J Endocrinol. 2007 Aug; 157 (2): 209-13.

18. McLean AM, Fairclough PD. Endoscopic ultrasound in the localisation ofpancreatic islet cell tumours. Best Pract Res Clin Endocrinol Metab. 2005Jun; 19(2):177-93. Review.
19. Kann PH, Rothmund M, Zielke A. Endoscopic ultrasound imaging of insulinomas: limitations and clinical relevance. Exp Clin Endocrinol Diabetes. 2005 Sep; 113(8):471-4.

20. Tseng LM, Chen JY, Won JG, Tseng HS, Yang AH, Wang SE, Lee $\mathrm{CH}$. The role of intra-arterial calcium stimulation test with hepatic venous sampling (IACS) inthe management of occult insulinomas. Ann SurgOncol. 2007 Jul; 14 (7): 2121-7. Epub 2007 Apr 12.

21. Morera J, Guillaume A, Courtheoux P, Palazzo L, Rod A, Joubert M, Reznik Y. Preoperative localization of an insulinoma: selective arterial calcium stimulation test performance.J Endocrinol Invest. 2016 Apr;39 (4): 455-63. doi: 10.1007/s40618-015-0406-4. Epub 2015 Nov 17.

22. Guettier JM, Kam A, Chang R, Skarulis MC, Cochran C, Alexander HR, Libutti SK, Pingpank JF, Gorden P.Localization of insulinomas to regions of the pancreas by intraarterial calcium stimulation: the NIH experience. J Clin Endocrinol Metab. 2009 Apr; 94 (4): 1074-80. doi: 10. 1210/jc. 2008-1986. Epub 2009 Feb3.

23. Chung JC, Choi SH, Jo SH, Heo JS, Choi DW, Kim YI. Localization and surgical treatment of the pancreatic insulinomas. ANZ J Surg. 2006 Dec;76(12):1051-5.

24. Jackson JE. Angiography and arterial stimulation venous sampling in the localization of pancreatic neuroendocrine tumours.Best Pract Res Clin Endocrinol Metab. 2005 Jun;19(2):229-39.

25. Gimm O, König E, Thanh PN, Brauckhoff M, Karges W, Dralle H. Intra-operative quick insulin assay to confirm complete resection of insulinomas guided byselective arterial calcium injection (SACI). Langenbecks Arch Surg. 2007 Nov; 392 (6): 679-84. Epub 2007 Feb 9.

26. Tseng HC, Yao CZ, Zhong SX, Zhang JX, Zhu Y. Percutaneous transhepatic portal vein catheterization for localization of insulinoma. World J Surg. 1984Aug; 8 (4): 575-82.

27. Kaczirek K, Ba-Ssalamah A, Schima W, Niederle B. The importance of preoperative localisation procedures in organic hyperinsulinism- experience in 67 patients. Wien Klin Wochenschr. 2004 Jun 30; 116 (1112): 373-8. Pub Med PMID:15291289. 


\section{Original Research Article}

28. Gritzmann N, Macheiner P, Hollerweger A, Hübner E. CT in the differentiation of pancreatic neoplasms-progress report. Dig Dis. 2004; 22(1):6-17.

29. Akerström G, Hellman P, Hessman O, Osmak L. Surgical treatment of endocrine pancreatic tumours. Neuroendocrinology. 2004;80 Suppl 1:62-6.

30. de Herder WW. Insulinoma. Neuroendocrinology. 2004; 80 Suppl 1:20-2.

31. Vázquez Quintana E. The surgical management of insulinoma.BolAsoc Med P R.2004 Jan-Feb;96(1):33-8.

32. Lairmore TC, Moley JF. Endocrine pancreatic tumors. Scand J Surg. 2004; 93 (4):311-5. Review. Pub Med PMID: 15658673.

33. Jyotsna VP, Rangel N, Pal S, Seith A, Sahni P, Ammini AC. Insulinoma: Diagnosis and surgical treatment. Retrospective analysis of 31 cases. Indian J Gastroenterol. 2006 Sep-Oct;25(5):244-7.

34. Kaczirek K, Ba-Ssalamah A, Schima W, Niederle B. The importance of preoperative localisation procedures in organic hyperinsulinism--experience in 67 patients. Wien Klin Wochenschr. 2004 Jun 30; 116 (11-12):373-8.

35. Jensen RT, Cadiot G, Brandi ML, de Herder WW, Kaltsas G, Komminoth P, Scoazec JY, Salazar R, Sauvanet A, Kianmanesh R; Barcelona Consensus Conference participants. ENETS Consensus Guidelines for the management of patients with digestive neuroendocrine neoplasms: functional pancreatic endocrine tumorsyndromes. Neuroendocrinology. 2012; 95 (2):98119. doi: 10.1159/000335591. Epub2012 Feb 15.

36. Kulke MH, Anthony LB, Bushnell DL, de Herder WW, Goldsmith SJ, Klimstra DS, Marx SJ, Pasieka JL, Pommier RF, Yao JC, Jensen RT; North American NeuroendocrineTumor Society (NANETS). NANETS treatment guidelines: well-differentiatedneuroendocrine tumors of the stomach and pancreas. Pancreas. 2010 Aug; 39 (6): 735-52. doi:10.1097/MPA.0b013e3181e bb168.

37. Crippa S, Zerbi A, Boninsegna L, Capitanio V, Partelli S, Balzano G, Pederzoli P, Di Carlo V, Falconi M. Surgical management of insulinomas: shortandlong-term outcomes after enucleations and pancreatic resections. Arch Surg. 2012 Mar;147(3):2616. doi: 10.1001/archsurg.2011.1843.
38. Laje P, Stanley CA, Palladino AA, Becker SA, Adzick NS. Pancreatic headresection and Roux-en-Y pancreaticojejunostomy for the treatment of the focal form of congenital hyperinsulinism. J Pediatr Surg. 2012 Jan; 47(1):130-5. doi:10.1016/j.jpedsurg. 2011. 10.032 .

39. Shoup M, Brennan MF, McWhite K, Leung DH, Klimstra D, Conlon KC. The value of splenic preservation with distal pancreatectomy.Arch Surg. 2002 Feb;137(2):164-8.

40. Mabrut JY, Fernandez-Cruz L, Azagra JS, Bassi C, Delvaux G, Weerts J, Fabre JM, Boulez J, Baulieux J, Peix JL, Gigot JF; Hepatobiliary and Pancreatic Section (HBPS) of the Royal Belgian Society of Surgery; Belgian Group for Endoscopic Surgery (BGES); Club Coelio. Laparoscopic pancreatic resection: results of amulticenter European study of 127 patients. Surgery. 2005 Jun;137(6):597-605.

41. Goletti O, Celona G, Monzani F, Caraccio N, Zocco G, Lippolis PV, Battini A, Seccia M, Cavina E. Laparoscopic treatment of pancreatic insulinoma. Surg Endosc. 2003 Sep;17(9):1499. Epub 2003 Jun 17. Pub Med PMID: 12802660.

42. Jaroszewski DE, Schlinkert RT, Thompson GB, Schlinkert DK. Laparoscopic localization and resection of insulinomas. Arch Surg. 2004 Mar; 139 (3): 270-4.

43. Roland CL, Lo CY, Miller BS, Holt S, Nwariaku FE. Surgical approach and perioperative complications determine short-term outcomes in patients with insulinoma: results of a bi-institutional study. Ann Surg Oncol. 2008 Dec; 15(12):3532-7. doi: 10.1245/s10434008-0157-y. Epub 2008 Sep 30.

44. Jürgensen C, Schuppan D, Neser F, Ernstberger J, Junghans U, Stölzel U. EUS-guided alcohol ablation of an insulinoma. Gastrointest Endosc. 2006 Jun; 63(7): 1059-62

45. Limmer S, Huppert PE, Juette V, Lenhart A, Welte M, Wietholtz H. Radio frequency ablation of solitary pancreatic insulinoma in a patient with episodes of severe hypoglycemia. Eur J Gastroenterol Hepatol. 2009 Sep; 21 (9): 1097-101.

46. Moore TJ, Peterson LM, Harrington DP, Smith RJ. Successful arterial embolization of an insulinoma. JAMA. 1982 Sep 17; 248 (11): 1353-5. 


\section{Original Research Article}

47. Uflacker R. Arterial embolization as definitive treatment for benigninsulinoma of the pancreas. J Vasc Interv Radiol. 1992 Nov;3(4):639-44; discussion 644-6.

48. Vezzosi D, Bennet A, Courbon F, Caron P. Shortand long-term somatostatin analogue treatment in patients with hypoglycaemia related to endogenoushy perinsulinism. Clin Endocrinol (Oxf). 2008 Jun; 68 (6): 904-11.Epub 2007 Nov 19.

49. Kishikawa H, Okada Y, Hirose A, Tanikawa T, Kanda K, Tanaka Y. Successful treatment of insulinoma by a single daily dose of octreotide in two elderly female patients. Endocr J. 2006 Feb;53(1):79-85.

50. Katabami T, Kato H, Shirai N, Naito S, Saito N. Successful long-term treatment with once-daily injection of low-dose octreotide in an aged patient with insulinoma. Endocr J. 2005 Oct;52(5):629-34.

51. Bonato FT, Coelho JC, Petruzzielo A, Matias JE, Ferreira GA. Surgical treatment of pancreatic insulinomas. Arq Bras Cir Dig. 2012 Apr-Jun; 25 (2): 101-4.

\section{How to cite this article?}

Chinthakindi M, Prashanth K, Thogari R, Reddy R.P. A study of Diagnosis and surgical management of pancreatic insulinoma. Surgical Update: Int J surg Orthopedics.2018;4(1):59-67.doi:10.17511/ijoso.2018.i01.10. 